\title{
Ethical Firms and Web Reporting: Empirical Evidence about the Voluntary Adoption of the Italian "Legality Rating"
}

\author{
Fabio Caputo ${ }^{1} \&$ Simone Pizzi ${ }^{1}$ \\ ${ }^{1}$ Department of Economic Sciences, Università del Salento, Lecce, Italy \\ Correspondence: Simone Pizzi, Department of Economic Sciences, Università del Salento, Lecce, 73100, Italy. \\ E-mail: simone.pizzi@unisalento.it
}

Received: November 11, 2018

doi:10.5539/ijbm.v14n1p36

\begin{abstract}
In 2012, Italy introduced the "Legality Rating" into its legal system. The purpose of this rating is to support the most virtuous companies in terms of access to credit and in the granting of state contributions through a reward system that provides for the possibility of maturing different levels of quality. The growing number of ratings assigned in 2018 suggests that this instrument is gradually gaining notoriety and credibility on the part of entrepreneurs. However, the achievement of the qualifications necessary for the issue of the rating still appears to be a choice made by managers exclusively for utilitarian purposes rather than for reasons connected to a growing sensitivity to CSR issues. The results show that the use of the instrument favors the improvement of the financial economic performance of the companies. However, it emerges that only few companies communicate their good practices on their own websites.
\end{abstract}

Keywords: legality rating, accountability, reporting, web reporting, disclosure, financial performance

\section{Introduction}

\subsection{Strategic role of CSR in the European scenario}

The recent economic scenario is characterized by a high level of competition between companies. Among the various reasons that have contributed to accentuating this operational complexity is the central role played by the development of web technologies that have improved the interaction between customers and suppliers and, indirectly, the globalization of the markets (Hauman and Heimenshof, 2014).

In this regard, it is therefore clear that companies have been induced to identify new operational paradigms to consolidate, or increase, their competitive advantage. From the perspectives of the firms, this need is higher in sectors characterized by "controversial" competitors due the risks of greenwashing by them (Aqueveque et al., 2018). In this sense, the growing attention paid by managers, and by the entire community, regarding the CSR themes plays a significant role due to the different implications connected to the adoption, or not, of this paradigm by the firms. In this sense, for the managers the adoption of ethical behavior represents one of the main strategic drivers to increase the degree of reputation connected to their companies. In fact, the achievement of a higher level of reputation by the firms represents a strategy that is useful to improve their market share and to find new customers (Alwi et al., 2017). Moreover, some of the most recent legislative interventions proposed by the institutions have involved issues related to CSR (Polonsky and Jevons, 2009, Acquier et al., 2017).

In Europe, the adoption of these kinds of ethical strategies was encouraged by the legal provisions produced by the Governments (Steurer et al., 2015; Venturelli and Caputo, 2017). Specifically, the issue of ESG reporting has assumed a strategic role within the regulatory processes that have characterized the recent economic policy directions affecting the European scenario. In this sense, the recent Directive EU / 2014/95 concerning the subject of non-financial reporting is the latest, in order of time, intervention concerning the gradual harmonization of Community legislation regarding the mandatory reporting of businesses regarding these issues. The transposition of this directive is therefore to intervene, limited to specific categories of companies identified for each context by internal legislation, within a community's economic fabric characterized by distinct levels of sensitivity with respect to these issues in the absence of mandatory regulation (Venturelli et al., 2017; Matuszak and Rozanska, 2017; Dumitru et al., 2017). 


\subsection{The Italian "Legality rating"}

Within this community scenario, however, it should be noted that over the years national legal provisions have been implemented within national laws with the aim of encouraging their use by companies of socially responsible behavior. The recent regulatory measures that have taken place within the Italian legal framework have, in fact, seen the insertion within the legal system of tools aimed at sensitizing the entrepreneurs, and indirectly the stakeholders, to the CSR themes. In this sense, one of the main legislative provisions concerning these issues had as its object the introduction of the legality rating tool. The legality rating, introduced within the Italian legal system through Decree Law 1/2012 and subsequently ratified by Law 62/2012, represents, according to the legislator's vision, an instrument aimed at favoring the diffusion of a business culture more oriented to issues related to legality and ethics. In this sense, the legality rating could be considered a "reputational instrument" for the firms (Ginesti et al., 2018). Specifically, the rating aims to measure through the attribution of a number of "stars" the non-financial performance of the companies. The issue of the rating sees, in fact, a first level of adherence characterized mainly by the absence of penal and administrative convictions by the subjects operating within the company, and two successive levels characterized by typically optional elements, among which, by way of example, the adoption of the 231 model, the production of sustainability reports and the existence of an internal code of ethics. In this sense, with a view to encourage its adoption, the legislator has provided a reward system for companies following self-declaration under the external supervision of the AGCM (Italian Competition Authority). For example, through the Decree n.57 issued by the MEF-MISE on 20 February 2014, specific obligations have been envisaged regarding the relationship with the public administrations and banking institutions. The number of companies that have chosen to adopt the legality rating is constantly growing. In fact, in 2018, 6488 companies were certified, of which 5394 were assigned to the first allocation and 1063 subjected to a renewal procedure. In the same year, the supervisory authority adopted 31 measures to revoke the rating and a suspension (Table 1). From a qualitative point of view, it should be noted that the level of adhesion to the rating by the companies is still medium to low, reflecting how these practices are not yet fully understood by the company.

Table 1. Our elaboration on AGCM data

\begin{tabular}{lcc}
\hline Status & Observation & \%Impact \\
\hline Rating Renewed & 1063 & $16,38 \%$ \\
Rating Attributed & 5394 & $83,14 \%$ \\
Rating Revoked or suspensed & 31 & $0,48 \%$ \\
Total & 6488 & $100,00 \%$ \\
\hline
\end{tabular}

\subsection{Literature Review}

The issue of the legality rating is inserted within the literature field concerning voluntary non-financial disclosure. This line of research is widely dealt with in the literature concerning CSR. In fact, as highlighted by previous meta-analytical studies, it is evident that the voluntary character is predominant within the CSR definitions proposed in the literature of major importance in the economic-business context (Dahlsrud, 2008).

Over the years there have been several studies on the determinants able to positively affect the voluntary adoption by companies of CSR instruments. These studies highlight how the development of CSR has been favored over time by the recognition of strategic value by managers in these activities. The recognition of this strategic value stems from the growing attention by managers to new issues useful for the growth of competitive advantage (Neville et al., 2005; Prado-Lorenzo et al., 2009; Sierra-Garcia et al., 2015; Manes-Rossi et al., 2017) and incentives to support such practices promoted by government agencies (Steurer, 2010; Battaglia et al., 2010). Specifically, the main studies conducted by scholars find their foundation in previous studies that have shown how one of the most important strategic drivers to increase the competitive advantage is represented by the reputational component (Hall, 1993; Kumar and Pansari, 2016). In this regard, the theme of CSR is particularly relevant and, as highlighted in previous studies, represents one of the main means capable of increasing this intangible corporate component (Fombrun, 2005; Hillenbrand and Money, 2007). CSR is, in fact, a means able to differentiate the company from competitors through the reporting to the market of its non-financial activities (Lys et al., 2015). This process, defined as stakeholder engagement, aims to involve the main internal and external stakeholders in the organizational and decision-making processes (Freeman, 2010). Empirical results show that this phenomenon is positively correlated with the size of the companies involved, due to the greater number of stakeholders involved in internal and external processes (Chan et al., 2014). Furthermore, companies 
engaged in these activities can often benefit indirectly from greater attention from the media regarding their activities, thus generating as a positive externality an effective increase in popularity, and therefore reputation, among stakeholders (Cahan et al., 2015).

Studies supporting the positive relationship between CSR and business performance are based on the theory defined Resource Based View (Torugsa et al., 2012; Wang \& Sarkis, 2017; Platonova et al., 2018; Hanas et al., 2018). Specifically, this theory finds application in the field of CSR studies according to two different perspectives of analysis (Branco and Rodrigues, 2006). According to the "internal" perspective, through the use of specific company resources in these activities, companies can improve their competitive advantage through the sharing of knowledge and the progressive process of mutual learning among the parties involved (Venturelli et al., 2018). The development of new skills within the organization entails the possibility of redefining company strategies, according to principles aimed at improving the effectiveness and efficiency of operations conducted (Orlitzky et al., 2003). According to the "external" perspective, the competitive advantage deriving from the adoption of socially responsible practices is closely linked to the company's reputation. Improving corporate reputation is one of the strategic levers of the company that cannot be directly controlled by management. Considering this evidence, literature shows that CSR indirectly implies better financial performance due to its natural ability to support the generation of value over time (Siltaoja, 2006). However, it should be noted, in this regard, that a part of literature, albeit in a minor way, demonstrates the absence of direct links between the two phenomena (Barnett and Salomon, 2012).

\section{Hp1: Companies with a high CSR rating improve their economic, financial and equity performance.}

The relevance of companies' web reporting activities has been favored by the growing use by the stakeholder of new form of digital platforms like web sites, Facebook, LinkedIn and Twitter (Kent and Taylor, 2016). In particular, this evolution regards CSR communications (Etter, 2013). It should be noted that web reporting has undergone significant changes due to the increase in users, which has resulted in an automatic increase in interactions between customers and companies (Capriotti, 2011). This change has led, from a communicative point of view, to the transition from Web 1.0 to Web 2.0. The advent of web 2.0 has deeply affected the strategies connected to the communication of non-financial activities promoted by the companies. This change therefore involves the transformation of customers due the possibility to compare firms' activities in real time with the use of digital instruments. Specifically, through the creation of communities or opinion groups, the consumer goes from user to subject who uses and reviews the product or service purchased (Ihlen et al., 2011). Web reporting is even relevant for investors who have the possibility to find out more information about firms (Saleh and Roberts, 2017). However, despite the great attention paid by scientific literature (Brennan and Merckl-Davies, 2018), previous empirical studies show that companies still tend not to use this communication tool (Cortado and Chalmeda, 2016). In fact, the absence of specific regulations about these themes could represent an obstacle to the full achievement of this target. According to previous empirical studies, firms who produced sustainability or integrated reports disclosed only a few parts of the non-financial information achieved on their website throughout the year (Alvarez-Gonzalez et al., 2018; Bosetti, 2018).

\section{Hp2: Companies with a high CSR rating recognize the role of Web 2.0 in their CSR communication.}

\subsection{Our Purpose}

In accordance with previous literature (Doni et al., 2016; Ginesti et al., 2018), the purpose of this article is to evaluate the effective impact of the legality rating on Italian companies in terms of economic, financial and equity performance. Specifically, the present research has as object of study the most virtuous companies in terms of legality rating, ie those with 3 stars. In this regard, the research methodology is structured in two different levels of analysis. The first type of statistical analysis is descriptive and aims to identify, through a content analysis conducted on the websites of the companies being analyzed, the main elements adopted by Italian companies to improve their legality rating. In this regard, a legality score will be provided, to highlight how, within the same category, it is possible to identify a different level of virtuosity on the part of companies. The second type of analysis involves the use of a panel-type analysis to evaluate, through econometric techniques, the impact of the introduction of the legality rating within company systems on economic and financial performance.

\section{Method}

The sample under investigation consists of 148 companies which, at the date of the survey, are in possession of a legality rating equal to "***". The sample was extracted from the official database provided by AGCM. To consider a sample characterized by a high degree of homogeneity within the surveys, a cluster of 148 companies, which provided data on their legality rating within their own site, was extracted from the population. Our cluster 
represents $58,04 \%$ of the companies with a rating equal to $* * *$. This methodological approach, although in the possession of critical physiological issues, respects what is outlined in some of the most authoritative statistical studies on the social research methodology (Barrow, 2009).

The first part of the research concerns the evaluation of the effects connected to the attribution of the legality rating on the economic, financial and equity performance of the companies. According to similar previous studies, this analysis was carried out through a panel data type regression analysis. The panel investigated consists of 740 observations concerning the 148 companies during the period from 2012 to 2016 . To evaluate which is the most precise panel data model between fixed or random effect, we used the Hausman test. This test evaluates the significance level between estimators, in the case of fixed effect or random effect models (Hausman, 1978).

To assess the impact of the legality rating on the different aspects related to company performance we proceeded to define three different models of analysis. According to previous studies about the impact of CSR on a firm's performance, we used the most used accounting-based measures to evaluate the relation between the two aspects (Lu et al., 2014; Wang et al., 2016). Specifically, the three models envisage, as dependent variables, respectively the natural logarithm of the EBIDTA for the reference year (Awan and Saeed, 2015; Boesso et al.,2015), the DEBT / EQUITY ratio (Benlemlih, 2017) and the LIQUIDITY RATIO (Kim and Im, 2017; Yilmaz, 2016). To allow for the comparison of the three models, it was decided to identify common independent variables with the use of AIDA database. Specifically, we considered in our models: leverage (LEV), return on asset (ROA) and number of employees (SIZE). Finally, to evaluate the impact of the legality rating on our dependent variables, we use the dummy variable (LEG).

The structural forms associated with the following equations are:

$$
\begin{gathered}
\text { MODEL1: } E B I D T A_{I, J}=L E G_{i, j}+L E V_{i, j}+R O A_{i, j}+S I Z E_{I, J}+\varepsilon_{i, j} \\
\text { MODEL2:DE } E_{I, J}=L E G_{i, j}+L E V_{i, j}+R O A_{i, j}+S I Z E_{I, J}+\varepsilon_{i, j} \\
\text { MODEL3: } L R_{I, J}=L E G_{i, j}+L E V_{i, j}+R O A_{i, j}+S I Z E_{I, J}+\varepsilon_{i, j}
\end{gathered}
$$

The descriptive statistics associated with the variables are as follows:

Table 2. Variable description

\begin{tabular}{llllll}
\hline Variables & Mean & Median & St.Dev & Min & Max \\
\hline EBIDTA (mil.) & 11,5 & 34,4 & 76,9 & 66,7 & 1.340 \\
DE & 1,42 & 0,665 & 2,92 & $-2,13$ & 50,5 \\
LR & 1,38 & 1,15 & 0,918 & 0,05 & 7,67 \\
SIZE & 10,3 & 10,1 & 2,03 & 2,23 & 18,1 \\
ROA & 4,43 & 3,54 & 6,07 & $-31,9$ & 36,9 \\
LEV & 7,54 & 4 & 13,3 & $-18,4$ & 174 \\
LEG & 0,108 & 0 & 0,311 & 0 & 1 \\
\hline
\end{tabular}

The second part of the research is of a statistical-descriptive nature, and aims to assess how, in the "***" category, the web communication is not heterogeneous in terms of non-financial information. Specifically, through an exploratory analysis of the websites of the companies belonging to the sample, the presence of the following elements was evaluated through a score. For our analysis, we considered only the voluntary items indicated by law to achieve the highest level of legality rating. 
Table 3. Variables description

\begin{tabular}{lll}
\hline Code & Variables & Value \\
\hline 231 & 231 Model & $0=$ absent; \\
& $1=$ present; \\
ACS $\quad$ Anticorruption System & $0=$ absent; \\
& & $1=$ present; \\
COE $\quad$ Code of ethics & $0=$ absent; \\
& & $1=$ present; \\
TOR $\quad$ Type of Report & $0=$ absent; \\
& & $1=$ Sustainability report; \\
& & $2=$ Annual report + Sustainability Report; \\
& & $3=$ Integrated Report; \\
WEB $\quad$ Web Reporting & & $0=$ absent; \\
& & $1=$ Standard setter
\end{tabular}

Following this activity, a "Legality Score" was measured by calculating a weighted average to assess, through a scale from 0 to 100 , the quality level of the disclosure reported by the companies. However, it should be noted that the investigation does not concern the actual verification of the possession of these requirements, but rather the management's ability to communicate to the stakeholders these aspects concerning the company's activities.

$$
\text { LegalityScore }=\text { Mean }(231, A C S, C O E, T O R, S S, A S S, W E B) \times 100
$$

\section{Results}

The first part of our analysis evaluated the relationship between the introduction of the legality rating and company performance in terms of improvement of the economic, financial and equity indicators. The goodness of the three models was evaluated with the $\mathrm{R}^{2}$ index. Also, the results of Hausman test revealed that unobserved individual effects are correlated with the regressors. This indicates that the fixed and between estimates differ from one another. Therefore, this study used the fixed effect model.

The analysis shows how the introduction of the legality rating corresponds to a general improvement in company performance according to the three different perspectives of the survey. In fact, it shows how the LEG variable appears to be statistically significant and in possession of coefficients capable of positively impacting the company's equilibrium.

Regarding economic performance, EBIDTA appears to be positively influenced by the LEG variable, similar to the ROA and SIZE control variables. In fact, the model shows that it is associated with a coefficient equal to 0.991 against the other two variables that have coefficients equal to 0.127 and 1.155 respectively.

The company's level of indebtedness, expressed through the DEBT / EQUITY index, is also influenced by the introduction of the legality rating. The nature of the index also makes the impact of the LEV variable on it discounted. However, the analysis of the beta suggests how the positive impact connected to the adoption of the LEG is higher than the negative effects connected to the LEV. This report $(0.462>0.176)$ therefore suggests how the instrument affects, at various levels, the company's ability to cope with its debts in a timelier manner. Literature shows that this effect derives not only from the best conditions of access to credit provided for by the Italian legislator, but also from the greater competitive advantage of companies stemming from the adoption of socially responsible strategies (McWilliams and Siegel, 2011). 
Finally, the liquidity ratio is improved following the adoption of the legality rating. As previously stated, this effect is connected to the legislator's choice to favor and encourage companies to use the instrument through the obligation for banks to provide more advantageous conditions in terms of credit disbursement.

\begin{tabular}{|c|c|c|c|c|c|c|}
\hline & \multicolumn{2}{|c|}{ EBIDTA } & \multicolumn{2}{|c|}{ DEBT/EQUITY } & \multicolumn{2}{|c|}{ LIQUIDITY RATIO } \\
\hline & Coeff. & Sig. & Coeff. & Sig. & Coeff. & Sig. \\
\hline const & $-6,321$ & $* * *$ & 0,934 & & 2,283 & $* *$ \\
\hline LEG & 0,991 & $* * *$ & $-0,462$ & $* *$ & 0,126 & $*$ \\
\hline LEV & $-0,022$ & $* * *$ & 0,176 & $* * *$ & $-0,002$ & \\
\hline ROA & 0,127 & $* * *$ & $-0,009$ & & 0,001 & \\
\hline SIZE & 1,155 & $* * *$ & $-0,071$ & & $-0,088$ & \\
\hline $\mathrm{R}^{2}$ & 0,856 & & 0,824 & & 0,775 & \\
\hline Hausman Test & $4,294^{*}$ & & $11,5262^{-}$ & & $10,01^{*}$ & \\
\hline Type of Panel & Fixed E & ffect & Fixed Ef & & Fixed E & \\
\hline Number of obs. & 627 & & 690 & & 713 & \\
\hline
\end{tabular}

The analysis of the websites of the companies surveyed shows that, against a legality rating of $* * *$, the level of information provided by the same is heterogeneous in the sample. This discrepancy derives from the additive nature of the elements under investigation because, as envisaged by the Italian legislator, the achievement of this quality level can be pursued through the possession, or use, of different types of instruments. Furthermore, the greater relevance to certain requisites recognized by the legislator gives management greater attention to the pursuit of these activities. By way of example, the role recognized in the 231 model within the Italian legal framework is highlighted, which, in addition to be an element useful for achieving the level of legality rating ***, represents an instrument able to mitigate the risk of compliance related to business activity. In fact, as part of the analysis, it emerges that the worst results are attributable to the dynamics relating to the preparation and subsequent validation of non-financial disclosures, which tend to represent an activity characterized by a high degree of complexity and are a deterrent to use by SMEs (Kechiche and Soparnot, 2012). In addition, the low value attributed to the aspects related to web reporting, which include within them several types of activities conducted via web, shows how the Italian context still has cultural limits related to the online dissemination of non-financial performance. This result therefore shows how the role assigned by management to these elements is mainly to support the pursuit of certification rather than to communicate the good practices implemented in the exercise of the business activity to the stakeholders.

Table 4. Descriptive statistics about the content of the web site

\begin{tabular}{ccccccccc}
\hline & Unit & 231 & COE & ACS & TOR & SS & ASS & WEB \\
\hline Observations & 151 & 78 & 110 & 51 & 58 & 41 & 13 & 59 \\
Observations $\%$ & $100 \%$ & $51,66 \%$ & $72,85 \%$ & $33,78 \%$ & $38,41 \%$ & $27,15 \%$ & $8,61 \%$ & $39,073 \%$ \\
\hline
\end{tabular}

This evidence is supported in the quantitative analysis related to the measurement of the "Legality Score". The average value of this indicator, equal to $36.63 \%$, suggests that Italian companies tend to underestimate the importance of the implemented activities on the web. Moreover, although in the presence of a median value below average, the minimum value of $0 \%$ further supports this thesis, highlighting how, in a context in which companies formally present particularly virtuous systems, there are cases of total absence of web communication of the results achieved. Finally, the value of the average standard deviation shows that this scenario appears to be widespread throughout the sample.

Table 5. Descriptive statistics about "Legality Score".

\begin{tabular}{llllll}
\hline & Mean & Median & Max & Min & Dev.St. \\
\hline $\begin{array}{l}\text { Legality } \\
\text { Score }\end{array}$ & $36,63 \%$ & $31,25 \%$ & $87,50 \%$ & $0,00 \%$ & 5,399 \\
\hline
\end{tabular}




\section{Discussion}

Recent Community and national policies have contributed positively to the introduction, within the European and Italian context, of instruments aimed at encouraging non-financial performance communication between companies and stakeholders.

Among the main instruments introduced by the Italian legislator, the legality rating represents one of the most important instruments to support the voluntary adoption of social responsibility practices by the firms. The relevance of the instruments is confirmed by the satisfaction of the Hypothesis 1. In fact, the Panel analysis shows how the introduction of ratings by companies generates, on average, the best results in terms of economic, financial and equity performance. This result confirms what is stated in the specific literature concerning other ethical standards. However, the reject of the Hypothesis 2 denotes how the companies presented different average levels of disclosure on their websites. This result suggests how the potentially benefits connecting to the adoption of social responsibility practices by the firms is not fully achieved.

As highlighted in literature, such "legal" effects should not be forgotten to combine the indirect effects and the greater competitive advantage deriving from the adoption of socially responsible policies within the strategic planning processes adopted by companies. From the interpretation of the two analyses, however, it emerges that the legality rating is still perceived by managers and entrepreneurs as a tool closely linked to obtaining the advantages envisaged by the legislator rather than as an instrument capable of communicating to the stakeholders their own virtuous practices. As highlighted by the above results, the legality rating is an effective driver in the context of the different dynamics concerning the financial and economic situation of companies. However, the analysis of company websites shows that, in a context in which some companies did not communicate their information, the level of information provided does not appear to be homogeneous within the sample. In fact, in the segment of the most virtuous companies in possession of the "***", the quantity of information provided by them is characterized by a standard deviation of 5.399 .

The managerial implications connected to this study lie in the possibility for companies to be able to increase their performance by obtaining the legality rating. Furthermore, in order to increase these performances, the study shows that Italian companies still present a low level of awareness regarding the opportunity to use digital tools as a vehicle for direct interaction with stakeholders.

The limitations related to this study derive from the lack of consideration in the sample, for reasons of opportunity, of companies with a rating lower than ***. Future studies may be addressed through the extension of the study to these other types of social structures to assess how the different rating levels affect company performance.

\section{References}

Acquier, A., Valiorgue, B., \& Daudigeos, T. (2017). Sharing the shared value: A transaction cost perspective on strategic CSR policies in global value chains. Journal of Business Ethics, 144(1), 139-152.

Álvarez-González, L., García-Rodríguez, N., \& Sanzo-Pérez, M. (2018). Online Voluntary Transparency in Spanish Retail Firms. Measurement Index and CSR-Related Factors as Determinants. Sustainability, 10(10), 3542.

Alwi, S. F. S., Ali, S. M., \& Nguyen, B. (2017). The importance of ethics in branding: Mediating effects of ethical branding on company reputation and brand loyalty. Business Ethics Quarterly, 27(3), 393-422.

Aqueveque, C., Rodrigo, P., \& Duran, I. J. (2018). Be bad but (still) look good: Can controversial industries enhance corporate reputation through CSR initiatives?. Business Ethics: A European Review, 27(3), 222-237.

Awan, A. G., \& Saeed, S. (2015). Impact of CSR on Firms' Financial Performance: A Case Study of Ghee and Fertilizer Industry in Southern Punjab-Pakistan. European Journal of Business and Management, 7(7).

Barnett, M. L., \& Salomon, R. M. (2012). Does it pay to be really good? Addressing the shape of the relationship between social and financial performance. Strategic Management Journal, 33(11), 1304-1320.

Barrow, M. (2009). Statistics for economics, accounting and business studies. Pearson Education.

Battaglia, M., Bianchi, L., Frey, M., \& Iraldo, F. (2010). An innovative model to promote CSR among SMEs operating in industrial clusters: Evidence from an EU project. Corporate social responsibility and environmental management, 17(3), 133-141.

Benlemlih, M. (2017). Corporate social responsibility and firm debt maturity. Journal of Business Ethics, 144(3), 
491-517.

Boesso, G., Favotto, F., \& Michelon, G. (2015). Stakeholder prioritization, strategic corporate social responsibility and company performance: further evidence. Corporate Social Responsibility and Environmental Management, 22(6), 424-440.

Bosetti, L. (2018). Web-Based Integrated CSR Reporting: An Empirical Analysis. Symphonya. Emerging Issues in Management, (1), 18-38.

Branco, M. C., \& Rodrigues, L. L. (2006). Corporate social responsibility and resource-based perspectives. Journal of business Ethics, 69(2), 111-132.

Cahan, S. F., Chen, C., Chen, L., \& Nguyen, N. H. (2015). Corporate social responsibility and media coverage. Journal of Banking \& Finance, 59, 409-422.

Capriotti, P. (2011). Communicating corporate social responsibility through the internet and social media. The handbook of communication and corporate social responsibility, 358-378.

Chan, M. C., Watson, J., \& Woodliff, D. (2014). Corporate governance quality and CSR disclosures. Journal of Business Ethics, 125(1), 59-73.

Cortado, F. J., \& Chalmeta, R. (2016). Use of social networks as a CSR communication tool. Cogent Business \& Management, 3(1), 1187783.

Dahlsrud, A. (2008), "How corporate social responsibility is defined: an analysis of 37 definitions", Corporate social responsibility and environmental management, Vol. 15 No. 1, pp. 1 - 13.

Doni, F., Rossetti, S., \& Verona, R. (2016). Defining an ethic and sustainability rating for companies: the "legality rating". Empirical evidence from Italy. In 28th International Congress on Social and Environmental Accounting Research (CSEAR).

Dumitru, M., Dyduch, J., GuȘe, R. G., \& Krasodomska, J. (2017). Corporate Reporting Practices in Poland and Romania-An Ex-ante Study to the New Non-financial Reporting European Directive. Accounting in Europe, $1-26$.

Etter, M. (2013). Reasons for low levels of interactivity:(Non-) interactive CSR communication in Twitter. Public Relations Review, 39(5), 606-608.

Fombrun, C. J. (2005). A world of reputation research, analysis and thinking-building corporate reputation through CSR initiatives: evolving standards. Corporate reputation review, 8(1), 7-12.

Freeman, R. E. (2010). Managing for stakeholders: Trade-offs or value creation. Journal of business ethics, 96(1), 7-9.

Ginesti, G., Caldarelli, A., \& Zampella, A. (2018). Exploring the impact of intellectual capital on company reputation and performance. Journal of Intellectual Capital, 19(5), 915-934.

Hall, R. (1993). A framework linking intangible resources and capabiliites to sustainable competitive advantage. Strategic management journal, 14(8), 607-618.

Hasan, I., Kobeissi, N., Liu, L., \& Wang, H. (2018). Corporate social responsibility and firm financial performance: The mediating role of productivity. Journal of Business Ethics, 149(3), 671-688.

Haucap, J., \& Heimeshoff, U. (2014). Google, Facebook, Amazon, eBay: Is the Internet driving competition or market monopolization?. International Economics and Economic Policy, 11(1-2), 49-61.

Hausman, J. A. (1978). Specification tests in econometrics. Econometrica: Journal of the Econometric Society, 1251-1271.

Hillenbrand, C., \& Money, K. (2007). Corporate responsibility and corporate reputation: Two separate concepts or two sides of the same coin?. Corporate Reputation Review, 10(4), 261-277.

Ihlen, Ø., Bartlett, J., \& May, S. (Eds.). (2011). The handbook of communication and corporate social responsibility. John Wiley \& Sons.

Kechiche, A., \& Soparnot, R. (2012). CSR within SMEs: Literature review. International Business Research, 5(7), 97

Kent, M. L., \& Taylor, M. (2016). From Homo Economicus to Homo dialogicus: Rethinking social media use in CSR communication. Public Relations Review, 42(1), 60-67.

Kim, J., \& Im, C. (2017). Study on Corporate Social Responsibility (CSR): Focus on Tax Avoidance and 
Financial Ratio Analysis. Sustainability, 9(10), 1710.

Kumar, V., \& Pansari, A. (2016). Competitive advantage through engagement. Journal of Marketing Research, 53(4), 497-514.

Lu, W., Chau, K. W., Wang, H., \& Pan, W. (2014). A decade's debate on the nexus between corporate social and corporate financial performance: a critical review of empirical studies 2002-2011. Journal of Cleaner Production, 79, 195-206.

Lys, T., Naughton, J. P., \& Wang, C. (2015). Signaling through corporate accountability reporting. Journal of Accounting and Economics, 60(1), 56-72.

Manes-Rossi, F., Nicolo, G., \& Orelli, R. L. (2017). Reshaping Risk Disclosure through Integrated Reporting: Evidence from Italian Early Adopters. International Journal of Business and Management, 12(10), 11.

Matuszak, Ł., \& Różańska, E. (2017). CSR Disclosure in Polish-Listed Companies in the Light of Directive 2014/95/EU Requirements: Empirical Evidence. Sustainability, 9(12), 2304.

Mcgunagle, D. M., Button, D., \& Zizka, L. (2016). The impact of corporate social responsibility communication on corporate reputation. i-Manager's Journal on Management, 10(4), 37.

McWilliams, A., \& Siegel, D. S. (2011). Creating and capturing value: Strategic corporate social responsibility, resource-based theory, and sustainable competitive advantage. Journal of Management, 37(5), 1480-1495.

Neville, B. A., Bell, S. J., \& Mengüç, B. (2005). Corporate reputation, stakeholders and the social performance financial performance relationship. European Journal of Marketing, 39(9/10), 1184-1198.

Orlitzky, M., Schmidt, F. L., \& Rynes, S. L. (2003). Corporate social and financial performance: A meta-analysis. Organization studies, 24(3), 403-441.

Platonova, E., Asutay, M., Dixon, R., \& Mohammad, S. (2018). The impact of corporate social responsibility disclosure on financial performance: Evidence from the GCC Islamic banking sector. Journal of Business Ethics, 151(2), 451-471.

Polonsky, M., \& Jevons, C. (2009). Global branding and strategic CSR: an overview of three types of complexity. International Marketing Review, 26(3), 327-347.

Prado-Lorenzo, J. M., Gallego-Alvarez, I., \& Garcia-Sanchez, I. M. (2009). Stakeholder engagement and corporate social responsibility reporting: the ownership structure effect. Corporate Social Responsibility and Environmental Management, 16(2), 94-107.

Saleh, A., \& Roberts, C. (2017). The impact of online corporate reporting quality on analyst following and properties of their EPS forecasts. Accounting and Management Information Systems, 16(1), 59-88.

Sierra-García, L., Zorio-Grima, A., \& García-Benau, M. A. (2015). Stakeholder engagement, corporate social responsibility and integrated reporting: An exploratory study. Corporate Social Responsibility and Environmental Management, 22(5), 286-304.

Siltaoja, M. E. (2006). Value priorities as combining core factors between CSR and reputation-a qualitative study. Journal of Business Ethics, 68(1), 91-111.

Steurer, R. (2010). The role of governments in corporate social responsibility: Characterising public policies on CSR in Europe. Policy Sciences, 43(1), 49-72.

Steurer, R. (2015). CSR and Governments: Public Policies on CSR in Europe. Corporate Social Responsibility, 240.

Tomaselli, G., \& Melia, M. (2014). The role of interactive technologies for CSR communication. Journal of International Scientific Publication, 8, 324-340.

Torugsa, N. A., O'Donohue, W., \& Hecker, R. (2012). Capabilities, proactive CSR and financial performance in SMEs: Empirical evidence from an Australian manufacturing industry sector. Journal of business ethics, 109(4), 483-500.

Venturelli, A., \& Caputo, F. (2017). Informativa non finanziaria e regulation: tendenze evolutive e relative implicazioni alla luce dell'emanazione del D. Lgs 254/16. McGraw-Hill education.

Venturelli, A., Caputo, F., Leopizzi, R., \& Pizzi, S. (2018). The state of art of corporate social disclosure before the introduction of non-financial reporting directive: a cross country analysis. Social Responsibility Journal.

Venturelli, A., Caputo, F., \& Pizzi, S. (2018). L'impatto del contratto di rete nei processi di 
internazionalizzazione: alcune evidenze empiriche sulle PMI italiane. MANAGEMENT CONTROL.

Wang, Q., Dou, J., \& Jia, S. (2016). A meta-analytic review of corporate social responsibility and corporate financial performance: The moderating effect of contextual factors. Business \& Society, 55(8), 1083-1121.

Wang, Z., \& Sarkis, J. (2017). Corporate Social Responsibility Governance, Outcomes, and Financial Performance. Journal of Cleaner Production.

Yilmaz, I. (2016). Social Performance vs. Financial Performance: CSR disclosures as an indicator of Social Performance. International Journal of Finance \& Banking Studies, 2(2), 53-65.

\section{Copyrights}

Copyright for this article is retained by the author(s), with first publication rights granted to the journal.

This is an open-access article distributed under the terms and conditions of the Creative Commons Attribution license (http://creativecommons.org/licenses/by/4.0/). 